\title{
Semarang, From a Traditional City to a Modern City: Environmental Changes in History Perspective
}

\author{
Putri Agus Wijayati \\ \{putrikediri1962@gmail.com\} \\ Universitas Negeri Semarang, Indonesia
}

\begin{abstract}
Entering the first half of the 21 st century, environmental issue is a part of a perspective and a new approach in Indonesia's historiography. In the context of environmental issues, this historical study discusses the formation of the Semarang environment which processes into a modern city. Beginning in the 19th century, it began to show its shape as an urban area which was marked by the increasingly active city government, in this case gemeente carried out city infrastructure development. This paper aims to understand the reality of the past on urban society and its environment which is part of the urban process itself. As an area which has been constructed from the beginning to become urban under the authority of the local authorities, in its development it turned out that it had been co-opted by the colonial state through changes in the system of government. The conclusion of this paper is become a modern city, gemeente Semarang has succeeded in making organizational changes and government administration as well as presenting a variety of modern infrastructures, but at the same time when faced with matters of upholding law and order in a modern urban environment, gemeente shows its inability. When the physical environment of the city has changed, it turns out that anomie or social disorganization was found in the modern city space of Semarang.
\end{abstract}

Keywords: traditional city, modern city, environmental changes, historical perspective.

\section{Introduction}

Two and a half decades ago, precisely in 1995, a Thai city planning adviser Douglas Webster assumed that the urban environment was a major problem for cities in Southeast Asia [1]. One of the problems faced by cities that have rapid growth is the occurrence of environmental changes. In many urban studies it is stated that environmental change affects humans and places, and environmental change is caused by human intervention [2]-[5]. Land use is caused by changes in the function of urban land, increasingly modern transportation, and urbanization represents change in the environment that is accelerated by urban population that is constantly increasing [6]-[12].

Changes in the urban environment caused by land use that result in changes in physical environment as mentioned above, also experienced by cities changed by the environment in Indonesia. One of the cities in Indonesia that improves similar conditions, namely Semarang. Until the 18th century, as a city that had the character of the city the northern coast of Java had been formed by several Asian merchant communities who settled in the urban villages as separately. The urban environment in that century is a space of social and cultural heterogeneity, in which various languages are spoken and various habits are practiced [13] Social heterogeneity becomes congested in the economic space of the city [14], [15], which is called the market, and this is the place that characterizes the city's economy [16]. In addition, 
city defenses landscape that were marked by existence of a fortress equipped with military armories and warehouses of ttade commodities belonging to Europeans. As in Figure 1

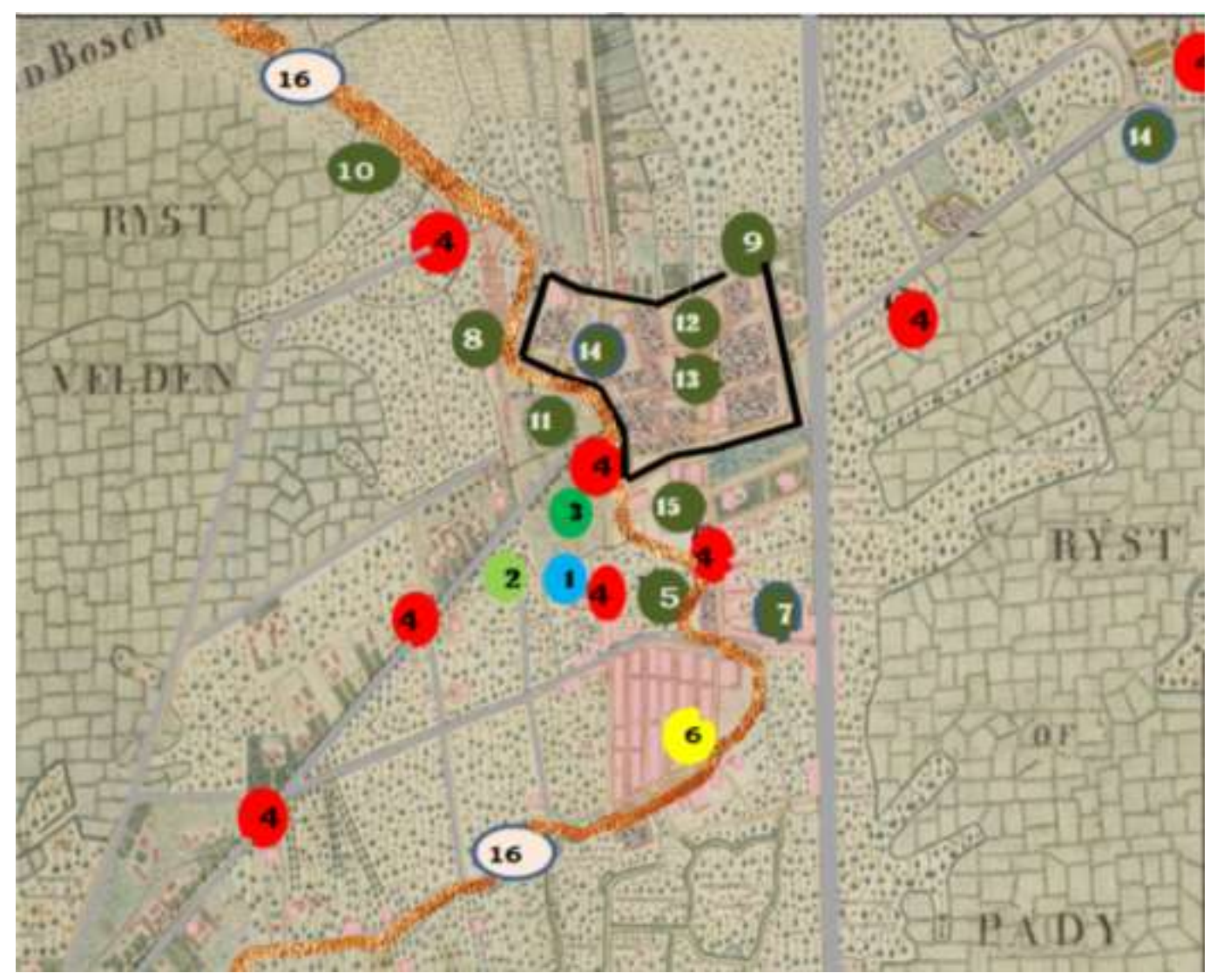

Figure 1. Map of Semarang in 1800

(Information:1)Ndalem; 2)Mosque; 3)Alun-alun (The square); 4)Markets; 5)Pedamaran Kampong; 6)Pecinan Kampong; 7 Moor Kampong; 8)Kampung Melayu; 9) Bugis Kampong; 10)Bandar (tol huise); 11) Military school; 12) Artillery Complex; 13) Church; 14) Government Pakhuizen; 15) Military Barracks and Stables; 16) Semarang River. Plan adapted from Plane of Platte Grond van Samarang Met Dies Environs of Een Afstand.

(Source:http:/www.gahetna.nl/en/collectie/afbeeldingen/KaarteCollectie/zoeken/weergave/det ail/start/3/tstart/0/q/zoekterm/kaart\%20semarang. Accessed 27-03-2015)

Until the end of the 18th century, the structure of the growth environment of the city of Semarang had formed a vertical structure or orthogonality defense [17]. This growth has shifted since the beginning of the 19th century, when Daendels issued a post highway policy (The Grote Postweg), a modern road that connects large cities on the north coast of Java [18]. The Megaproyek Jalan Pos from western Java to the eastern end of Java passing through Semarang has brought great changes to this city with all the consequences that accompany it. The opening of The Grote Postweg influenced the urban environment, both at the economic 
and political level in a country that offered colonialism called the Dutch East Indies government. In some historiographic reviews, the construction of highways presents a narrative of the socio-economic influence of the population and the regions it passes through. Meanwhile, the environmental changes that have taken place from the area through which the project is still excluded from historical narratives.

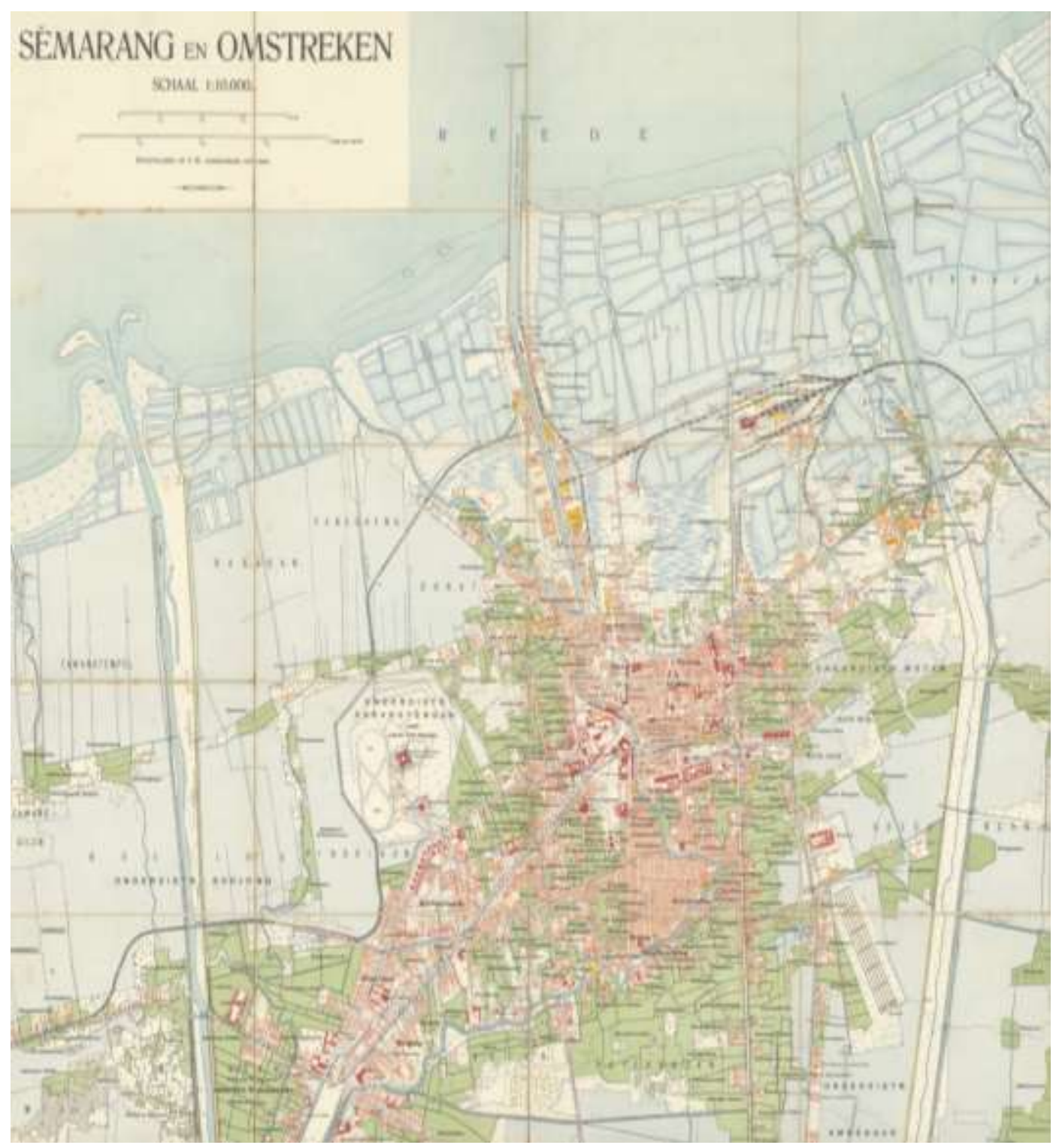

Figure 2. Map of Semarang in 1909

(Information: The pink color in the map above shows the development of settlements, while the green color as a sign of green land decreases. 
Groote Postweg or Daendels Street

(Source:http:/www.gahetna.nl/en/collectie/afbeeldingen/KaarteCollectie/zoeken/weergave/det ail/start/3/tstart/0/q/zoekterm/kaart\%20semarang. Accessed 27-03-2015).

In the context of environmental change, developments that have subsequently taken place have proven to have been exploiting land use, which originally turned into vertical [19]. The modernization of road infrastructure by Daendels has transformed the inland axis - the port (south - north) which relies on the role of water played by the Semarang River for almost three centuries (1500 - 1800 years) shifting into the west - east axis (see Figure 2). The path of growth that changed the transition from the interior to the coastal city of Semarang, which was renewed by development in residential areas, was enlarged by the settlements of the villages of Bumiputra. Borrowing the terminology used by Krausse to refer to urban villages as urban villages [20]. The initial form of growth Semarang's urban environment, if borrowed from Ford's way of thinking, reflects some aspects of urban ideology in the Netherlands [21], as well as other urban formation processes in Indonesia [22]-[25].

The growth of environmental growth has become one of the elements of the city that contributes to changes in the physical environment, both changes in land use, transportation use, and the development of anomic conditions in the social life of city residents. Based on the framework given in the section above, it cannot be denied that changes in the urban environment are a problem faced by cities in Indonesia, including in urban areas such as Semarang. The factual diversity in the past reality makes the element of urbanization, transportation, urban anomie an interesting and crucial thing to study in the context of environmental issues that are always actual in the 21 st century.

\section{Result and Discussion}

\subsection{City of Javanese Tradition, Building an Urban Environment}

Around the 6th century, an area on the north coast of Java which became embryonally then an alluvial land area as the beginning of the process of forming the urban environment of Semarang. The city was born from mud deposits which evolutively formed land, and then shifted the coastline to the sea [26]. Semarang is the only city on the north coast with the narrowest flat land, namely the distance between the sea and hills around three to four kilometers [27]. As a historical unit, Semarang grew into a traditional Javanese government that took place almost simultaneously with the Demak Sultanate (central Java) period around the 16th century. In the mid-16th century, the Demak government was disarmed and moved to Pajang [28], [29]. The evidence found led to the assumption that the third generation of Demak rulers named Made Pandan, who in the history of Semarang was considered the son of Pati Unus, traveled westward, and arrived in Semarang and then built a mosque. In the Javanese tradition, mosques are a space for religious life to reduce daily wrinkles and give meaning to time socially [30]. Made Pandan's son, namely Pandan Arang built a traditional Javanese urban area and as a symbol of power a district was established which was located in Bubakan [28], [31]. Before settling in Kanjengan (Ndalem), the district experienced displacement several times, including Gabahan and Sekayu, which eventually settled around Kanjengan, a central area of the Bumiputra government which had a square and religious symbols (see Figure 1). 
In the turn of the century, the process of Semarang's population was dominated by the involvement of external factors, especially the presence of Chinese traders, Malays, Arabs, Koja [32]. This condition was accelerated by the Vereenigde Oostindische Compagnie (VOC) decision when moving fortresses from Jepara to Semarang in the late 17th century as a center of control over rice production from the interior of Java. Semarang was an option, because the port of Jepara at the same time could not be used to dock for large VOC vessels. Ecological facts prove that the port of Jepara experienced siltation in the late 17th century [32]-[35].

The changes in Semarang's environment in the 18th century showed increasingly diverse settlements, especially around the Semarang River. There are urban villages that are synonymous with ethnic and tribal communities (see Figure 1), including Pedamaran Kampong, China Kampong, Moor Kampong, Kampung Melayu [36], Bugis Kampong [37], and ethnic Arabs [38] who lived partially in Kampung Melayu and others lived in Moor Kampong. In addition there are residential settlements Bumiputra also dominate urban villages in several other angles [35], [39]. The increasing population of cities that inhabit the village area, green land in the urban environment has diminished. Not limited to being used as a residential area, but also a variety of physical completeness of the city requires more extensive land. This resulted in Semarang's urban environment throughout the 18th century shows the dominance of land for planting rice called rice fields, dry land for perennials, and land in the form of forests began to decrease, then what happened later in the early 20th century green land began to decrease (see Figure 2). Unfortunately, no detailed data was found to reveal quantitative data to explain the decreasing environment of urban land in that century.

\subsection{Towards a Modern City}

Entering the beginning of the 20th century, Semarang as a city experienced rapid growth, both a physical environment, an increase in the population of the city, and modern urban infrastructure [40], as contained in the following news

"Iboe negeri Semarang pada masa ini makin bertambah sadja eloknja, sedang roemah" nja dibaharoei, malahan agaknja tiada berhentinja orang membangoenkan roemah ${ }^{2}$ gedong di pinggir djalan dalam kota. Slokan ${ }^{2}$ poen kebanjakan soedah diberi tamping batoe dan deras alir airnja, hingga menambahi kenjamanan badan dan kesenangan jang melihatnja. Kalau tiada salah, kota Semarang tiada boleh dibilang kedaton penjakit lagi seperti dahoeloe. Di kampung ${ }^{2}$ kota sudah banyak orang tinggal, ketjuali di bukit ${ }^{2}$ masih sedikit orangnja. Tetapi jang mendjadikan tjela pada iboe negeri ini, perkara tambangan dokar dan kereta terlaloe sedikit kalo ditimbang dengan besarnja negeri Semarang [41].

"The city of Semarang at this time grew elegantly, while the houses were renewed, in fact there was no doubt that people built buildings on the side of the road in the city. You can also find the ingredients given the batter and the heavy flow of water, adding to the comfort of the body and the pleasure that sees it. If there is nothing wrong, the city of Semarang can not be said to be a sickman again like the past. In the townships, people live, because there are still few people on the hills. But the one who made the case for the nation's mother, the case of the mining of buggies and trains was too little if it was weighed by the size of the land of Semarang"

The above quote provides an overview of Semarang's environment at the beginning of the 20th century, which was marked by increasingly active homes and building construction along roads, sewer repair, government attention to health aspects, and transportation infrastructure. In addition, in the above quote implicitly also conveyed the message that the beginning of 
1908 Semarang had become a dense residential area, while the hilly area located in the south of the city (Candi Baru area) had a still low population level. Some elements of urban modernization such as news content in Selompret Melajoe, not only show the existence of a process of becoming modern, more important than that is the increasing interaction between residents and urban environments [42], [43]. A colonial city environment idealized by Karsten as Indonesia's urban planning designer [44].

Entering the beginning of the 20th century, Semarang as a city experienced rapid growth, both a physical environment, an increase in the population of cities and modern urban infrastructure [40], as experienced by other cities in Indonesia, such as Jakarta and Surabaya [21], [22]. According to Ford, Jakarta, Semarang and Surabaya were constructed by colonial city planning designers imitating Dutch port cities equipped with walls, canals and churches [21]. The high migration of people from rural areas to the city has the biggest contribution to the growth of Semarang City [7]. The urban environment in the early 20th century influenced the growth of the Pasar Malam in Semarang [45]-[49]. Pasar Malam life has become a separate record for the city council to discuss it at gemeenteraad. Even the presence of the night market according to Economy news resulted in the lives of residents becoming involved in gambling, prostitution and crime [58]. Semarang as a modern colonial city is a change that cannot be avoided. There is a variety with sustainable development and discontinuities, between the progress and unpreparedness of socio-cultural communities that are excluded.

\section{Conclusion}

Through the process of environmental change, Semarang as an urban area with complete physical city continues to be built in the context of a colonial city through the status of gemeente (municipality). As a second historical reality, Semarang on the one hand "physically has become a symbol of urban colonialism", but on the other side the city of Semarang "is unable to let go of its past which has a rural element". Physically, the city authorities easily carried out the construction of a modern colonial city infrastructure. The existence of Semarang shows the colonial city in the midst of various changes that occurred. Through its geographical position as a trading city and port city, it is also a city for comfortable living and being right for a vacation for upper class residents. As a modern colonial city inherited, Semarang continues to improve in the midst of a constantly changing Indonesia. In the historical perspective that Semarang experienced from all processes, the power of Semarang as an urban area holds great potential to drive Indonesia's economic growth in the industrial and tourism sectors.

\section{References}

[1] D. Webster, "The Urban Environment in Southeast Asia: Challenges and Opportunities," Southeast Asian Aff., pp. 89-107, 1995.

[2] B. T. Robson, "The Urban Environment," Geography, vol. 60, pp. 184-188.

[3] D. Satterthwaite, "Environmental Transformations in Cities as They Get Larger, Wealthier and Better Managed," Geogr. J., vol. 163, pp. 216-224.

[4] A. Reid, "Environmental change , sustainable development and and citizenship," vol. 26, no. 2, pp. 72-76, 2001. 
[5] C. Greiner and P. Sakdapolrak, "Rural - urban migration , agrarian change , and the environment in Kenya : a critical review of the literature," vol. 34, no. 4, pp. 524-553, 2013.

[6] E. M. Berke and A. Vernez-Moudon, "Built environment change: a framework to support health-enhancing behaviour through environmental policy and health research," J. Epidemiol. Community Health, vol. 68, no. 6, pp. 586-590.

[7] T. R. Leinbach, "Rural Transport and Population Mobility in Indonesia," J. Dev. Areas, vol. 17, no. 3, pp. 349-364, 1983.

[8] G. E. Likens, "Viewpoint Human-accelerated environmental change," Bioscience, vol. 41, no. 3, p. 130.

[9] P. R. Pagliosaf, A. Fonsecaj, F. A. R. Barbosaf, and E. Bragaj, "Urbanization impact on Subtropical Estuaries: a Comparative Study of Water Properties in Urban Areas and in Protected Areas," J. Coast. Res., vol. II, no. 39, pp. 731-735, 2006.

[10] N. B. Grimm et al., "Global Change and the Ecology of Cities," Science (80-. )., vol. 319, no. 5864, pp. 756-760.

[11] K. Pauknerová, R. B. Salisbury, and M. Baumanová, "HUMAN-LANDSCAPE INTERACTION IN PREHISTORIC CENTRAL EUROPE: ANALYSIS OF NATURAL AND BUILT ENVIRONMENTS," Anthropologie, vol. 51, no. 2, 1962.

[12] I.-C. IP, "Urbanisation, the State, and Community Activism in the Pearl River Delta: The case of a land dispute in Dongguan," China Perspect., no. 2, pp. 53-60, 2014.

[13] J. Friedmann, "Cities in Social Transformation," Comp. Stud. Soc. Hist., vol. 4, no. 1, pp. 86-103.

[14] B. Purwanto, "Sejarah dan Jatidiri Dalam Ingatan Bersama Asia Tenggara," in Peradaban Pesisir, Menuju Sejarah Budaya Asia Tenggara, A. Vickers, Ed. Denpasar: Pustaka Larasan-Udayana University Press, 2009.

[15] J. S. Furnivall., Hindia Belanda, Studi Tentang Ekonomi Majemuk. Jakarta: Freedom Institute., 2009.

[16] M. Weber, "Apakah yang disebut Kota," in Masyarakat Kuno dan KelompokKelompok Sosial, Sartono Ka., Jakarta: Bhratara Karya Aksara, 1977, pp. 11-19.

[17] P. J. M. Nas and Pratiwo, "Jawa dan De Groote Postweg, La Grande Route, The Great Mail Road, Jalan Raya Pos," in Kota-Kota Indonesia, Bunga Rampai, P. J. M. Nas, Ed. Yogyakarta: Gadjah Mada University Press, 2007, p. 267.

[18] J. L. Van Zanden and D. Marks, Ekonomi Indonesia 1800-2010, Antara Drama dan Keajaiban Pertumbuhan. Jakarta: Penerbit Buku Kompas, 2012.

[19] P. J. M. dan P. Nas, "Jawa dan De Groote Postweg, La Grande Route, The Great Mail Road, Jalan Raya Pos,” in Kota-Kota Indonesia, Bunga Rampai, P. J. M. Nas, Ed. Yogyakarta: Gadjah Mada University Press, 2002, p. 253.

[20] G. Krausse, "Intra-Urban Variations in Kampung Settlements in Jakarta: a Structural Analysis," J. Trop. Geogr., no. 46, pp. 11-26.

[21] Larry R . Ford, "American Geographical Society A Model of Indonesian City Structure," Geogr. Rev., vol. 83, no. 4, pp. 374-396.

[22] T. R. Leinbach, "Economic growth, development planning and policy alternatives in Medan, Indonesia,” J. Southeast Asian Stud., vol. 18, pp. 118-140, 1987.

[23] S. Blackburn, Jakarta: Sejarah 400 Tahun. Jakarta: Jakarta: Masup Jakarta, 2011.

[24] J. Cote, “Thomas Karsten's Indonesia: Modernity and and the End of Europe, 19141945," Bijdr. tot Taal-, Land- en Volkenkd., vol. 170, №., no. 1, pp. 66-98, 2014. 
[25] D. Muhammad, "Semarang: Dari Bubakan Sampai Citraland," in Semarang Sepanjang Jalan Kenangan. Semarang, D. Muhammad, Ed. Semarang: Kerjasama Pemda Kodia Semarang-DKJT-Aktor Studio., 1995, p. 6.

[26] Soepono, Kota Besar Semarang. Semarang: Djawatan Penerangan Kota Besar Semarang, 1953.

[27] J. . Van Leur, Perdagangan dan Masyarakat Indonesia: Esai-Esai Tentang Sejarah Sosial dan Ekonomi Asia. Yogyakarta: Penerbit Ombak, 2015.

[28] Hadinoto., Perkembangan Kota di Jawa Abad XVIII Sampai Pertengahan Abad XX Dipandang dari Sudut Bentuk dan Struktur Kotanya. Yogyakarta: Penerbit Ombak., 2015.

[29] A. B. P. Wiryomartono, Seni Bangunan dan Seni Bina Kota di Indonesia. Jakarta: Gramedia Pustaka Utama, 1995.

[30] Sukirno, Semarang. Semarang: Djawatan Penerangan Kota Besar Semarang., 1956.

[31] et al Brommer, B., Semarang, Beeld van een Stad. Voorburg: Asia Maior., 1995.

[32] D. H. Burger and Prajudi, Sedjarah Ekonomis Sosiologis Indonesia. Djakarta: Pradnja Paramita, 1962.

[33] L. Nagtegaal, Riding the Dutch Tiger: the Dutch East Indies Company and the Northeast Coast of Java 1680-1743. Leiden: KITLV Press, 1996.

[34] Nawiyanto, "Coping with the Crises: Historical Comparison on Responses to the Crises in the Extreme Salient of Java," Tawarikh Int. J. Hist. Stud., vol. 4, no. 2, pp. 129-150, 2013.

[35] P. A. Wijayati, "Sejarah Sosial Pasar Johar Semarang Pada Abad Ke-20," Universitas Gadjah Mada Yogyakarta, 2019.

[36] J. A. Nagata, "Apa Itu Orang Melayu? Seleksi Identitas Etnik Berdasarkan Situasi dalam Suatu Masyarakat Majemuk," in Islam di Asia Tenggara: Perkembangan Kontemporer, dan Y. H. Ahmad Ibrahim, Sharon Siddique, Ed. Jakarta: LP3ES, 1990.

[37] G. Ammarell, "Bugis Migration and Modes of Adaptation to Local Situations," Ethnology, vol. 41, no. 1, 2002.

[38] van der Kroef and J. M, "The Arabs in Indonesia," Middle East J., vol. 7, no. 3, 1953.

[39] W. H. Frederick, "Hidden Change in Late Colonial Urban Society in Indonesia," J. Southeast Asia Stud., vol. XIV, no. 2, 1983.

[40] R. Mrózek, Engineers of Happy Land, Perkembangan Teknologi dan Nasionalisme di Sebuah Koloni. Jakarta: Yayasan Obor, 2006.

[41] "Kemadjoean dan Kemoendoeran Semarang," Selompret Melajoe, 21-Jan-1908.

[42] N. Ginsburg, "Kota dan Modernisasi," in Modernisasi Dinamika Pertumbuhan, M. Weiner, Ed. Yogyakarta: Gadjah Mada University Press, 1983, p. 71.

[43] J. LaPalombara, "Distribusi dan Pembangunan," in Modernisasi Dinamika Pertumbuhan, M. Weiner, Ed. Yogyakarta: Gadjah Mada University Press, 1983, p. 158.

[44] J. Cote, “Thomas Karsten's Indonesia: Modernity and and the End of Europe, 19141945," Bijdr. tot Taal-, Land- en Volkenkd., vol. 170, no. 1, pp. 93-95, 2014.

[45] “Pasar Malam," Selompret Melajoe, 27-Aug-1908.

[46] “Pasar Malam," Selompret Melajoe, 18-Aug-1908.

[47] “Pasar Malam Semarang," Medan Doenia, 18-Jul-1929.

[48] "Pasar- pasar Malem bikin malarat pada rajat," Economy, 26-Oct-1929.

[49] "Pasar - Malem doeloe dan Sekarang," Economy, 26-Jul-1939. 
